\title{
The Traditional Practice of Farmers' Legume-Cereal Cropping System and the Role of Microbes for Soil Fertility Improvement in North Shoa, Ethiopia
}

\author{
Befekadu Teshome*, Missiganaw Wassie and Endeshaw Abatineh \\ Microbial Biodiversity Directorate, Ethiopian Biodiversity Institute, Ethiopia \\ Submission: December 12, 2017; Published: January 26, 2018 \\ "Corresponding author: Befekadu Teshome, Microbial Biodiversity Directorate, Ethiopian Biodiversity Institute, Ethiopia, \\ Email: Beftesh@gmail.com
}

\begin{abstract}
This study aimed to assess the traditional practice of farmers in legume-cereal cropping systems in North Shoa, Ethiopia and their understanding about the role of microbes.

A total of 103 farmer-informants were selected using simple random sampling technique from the study area. A pre-tested and adjusted semi-structured interview questionnaire was designed and administered to explore farmers' soil classification techniques, farmers' indigenous and inherent techniques of soil fertility assessment, cropping systems and their knowhow about microbes associated with legume nodules and their effects in the improvement of soil fertility and growth of crops. Descriptive frequency statistics was used to evaluate all the variables using SPSS (2011) software ver.20.
\end{abstract}

The most three common traditional farming practices identified by this study are; crop rotation, sequential cropping, and strip cropping, respectively. The most common types of crops they combine during crop rotation are barley, bean, wheat, pea and linseed. This study also found out that most farmers living in the study area are aware of the role of legumes in soil improvement but they do not have the scientific background about the role of microbes associated with legume root nodules in the enhancement of soil fertility.

Keywords: Traditional knowledge; Microbes; Cropping system; North shoa; Ethiopia

\section{Introduction}

Legumes are potential sources of plant nutrients that complement/supplement inorganic fertilizers for cereal crops because of their ability to fix biological nitrogen (N) when included to the cropping systems. By fixing atmospheric $\mathrm{N} 2$, legumes offer the most effective way of increasing the productivity of poor soils either in monoculture, intercropping, crop rotations, or mixed cropping systems [1].

Crop rotation is a practice of rotating/changing the type of crops grown in the field each season or each year (or changing from crops to fallow). It is a key principle of conservation agriculture because it improves the soil structure and fertility, and because it helps control weeds, pests and diseases [2]. Farmers in ancient cultures as diverse as those of China, Greece, and Rome shared a common understanding about crop rotations. They learned from experience that growing the same crop year after year on the same piece of land resulted in low yields, and that they could dramatically increase productivity on the land by cultivating a sequence of crops over several seasons. They came to understand how crop rotations, combined with such practices as cover crops and green manures, enhanced soil organic matter, fertility, and tilth [3].

Intercropping is also an ancient practice, placed on the fringes of a 'modern agriculture' dominated by large areas of monocultured, resource-consuming and high-yielding crops. Intercropping is considered as a means to address some of the major problems associated with modern farming, including moderate yield, pest and pathogen accumulation, soil degradation and environmental deterioration, thereby helping to deliver sustainable and productive agriculture [2].

Intercropping has been widely practiced worldwide. It involves two or more crop species or genotypes growing together and coexisting for a time. This latter criterion distinguishes intercropping from mixed monocropping and rotation cropping. Intercropping is common, particularly in countries with high amounts of subsistence agriculture and low amounts of agricultural mechanization [2]. Developing countries such as Ethiopia, Niger, Mali China, India, and Indonesia have shown considerable interest in intercropping to enhance 
productivity [4]. In particular, cereal/legume intercropping is commonly employed in China and sub-Saharan Africa and has shown over-yielding and nutrient acquisition advantages under adverse conditions. Furthermore, intercropping also provides an important pathway to reduce soil erosion, fix atmospheric N2, lower the risk of crop failure or disease and increase land use efficiency [4].

Intercropping is often undertaken by farmers practicing low-input (high labour), low-yield farming on small parcels of land. Under these circumstances, intercropping can support increased aggregate yields per unit input, insure against crop failure and market fluctuations, meet food preference and/or cultural demands, protect and improve soil quality, and increase income. Intercrops can be divided into mixed intercropping (simultaneously growing two or more crops with no, or a limited, distinct arrangement), relay intercropping (planting a second crop before the first crop is mature), and strip intercropping (growing two or more crops simultaneously in strips, allowing crop interactions and independent cultivation) [2].

Various types of intercropping were known and presumably employed in ancient Greece about 300B.C. Theophrastus, among the greatest early Greek philosophers and natural scientists, notes that wheat, barley, millets and certain pulses could be planted at various times during the growing season often integrated with vines and olives, indicating knowledge of the use of intercropping [5]. Traditional agriculture, as practiced through the centuries all around the world, has always included different forms of intercropping. In fact, many crops have been grown in association with one another for hundred years and crop mixtures probably represent some of the first farming systems practiced [6]. Now a day, intercropping is commonly used in many temperate, tropical and subtropical parts of the world particularly by small-scale traditional farmers [7]. Traditional multiple cropping systems are estimated to still provide as much as $16-22 \%$ of the world's food supply [8].

In Ethiopia, plow agriculture in its current form as a dominant tool appears in rock painting dating as far back as 500AD. This annual crops (grain/cereal, legume and oil seed) based plow agriculture was centered in the central and northern highlands of Ethiopia. North Shoa is one of the major highlands of Ethiopia [9]. According to Encyclopaedia Britannica, 2017. Shewa, also spelled Showa, or Shoa, historic kingdom of central Ethiopia. It lies mostly on high plateau country, rising to 13,123 feet $(4,000 \mathrm{~m})$ in Mount Ābuyē Mēda. The geographical area of Shewa was formerly bounded on the northwest by the Blue Nile River and on the southwest by the Omo River; its eastern and southeastern boundaries were in the Great Rift Valley along the Awash River [10].

Even though it is difficult to find complete and exact information when and where crop rotation, intercropping and other traditional cropping systems were started in Ethiopia, it is understood that the practice of cropping began many centuries ago in Ethiopia. North Shoa, as it is ancient and central part of former Shoa where farming practiced for many centuries is assumed as one of the areas in Ethiopia where crop rotation and intercropping has been practiced by farmers for long time. These cropping systems are commonly used in many temperate, tropical and subtropical parts of the world particularly by small-scale traditional farmers. This study aimed to assess and document the traditional indigenous knowledge of farmers in their legume-cereal cropping systems in North Shoa of Ethiopia and attempted the level of farmers' understanding about the role of microbes in the soil fertility improvement.

\section{Materials and Methods}

\section{Description of study area and population}

The study was conducted from 10/02/09 to 15/02/09E.C in selected Kebeles (the smallest administrative units) of North Shoa zone. North Shoa (or Semien Shoa in Amharic) is one of the 11 zones in the Ethiopian Amhara Region (Figure 1). Semien Shoa takes its name from the kingdom or former province of Shoa. The Zone is currently bordered on the south and the west by the Oromia Region, on the north by South (Debub) Wollo, on the northeast by the Oromia Zone, and on the east by the Afar Region (CSA, 2007).

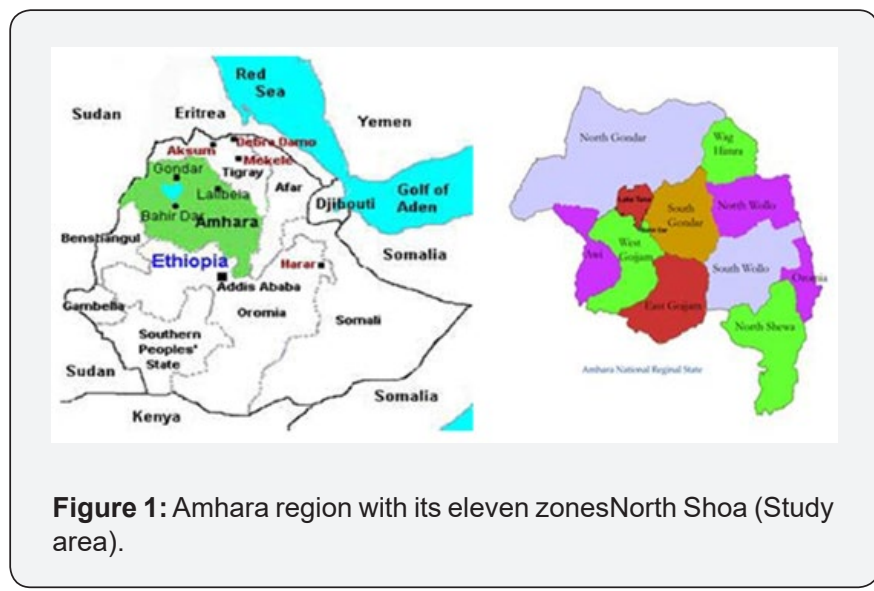

Based on the 2007 Census conducted by the Central Statistical Agency of Ethiopia (CSA), this Zone has a total population of $1,837,490$; with an area of $15,936.13$ square kilometers. Semien Shoa has a population density of 115.30 . While 214,227 or $11.66 \%$ are urban inhabitants, a further 112 or $0.01 \%$ are pastoralists. A total of 429,423 households were counted in this Zone, which results in an average of 4.28 persons to a household, and 413,235 housing units. The three largest ethnic groups reported in Semien Shoa were the Amhara (95.73\%), the Oromo (2.14\%), and the Argobba (1.71\%); all other ethnic groups made up $0.42 \%$ of the population. Amharic is spoken as a first language by $96.97 \%$, and $2.32 \%$ spoke Oromiffa; the remaining $0.71 \%$ spoke all other primary languages reported. $94.71 \%$ of the population said they practiced Ethiopian Orthodox Christianity, and $4.91 \%$ were Muslim (CSA, 2007). 


\section{Data collection: Sampling strategy and administration of interview questionnaires}

The research was undertaken in 8 kebeles of 4 woredas in North Shoa, Ethiopia, which were considered to be representative of the practice of cereal-legume intercropping system in the highland areas of Ethiopia. A semi-structured interview based survey was used to collect the data during the study $[11,12]$. In each kebeles, the research team randomly selected a representative group of farmers with different ages and social classes. The team used interview guides from the study woreda agricultural office during individual and group discussions so that the team members easily understand farmers' perceptions of soil fertility, techniques of soil classification, and their cropping systems. They also attempted to assess farmers' knowledge/knowhow of microbes associated with legumes and their effects in soil fertility improvement $[11,12]$.

A total of 103 farmer-informants were selected using simple random sampling technique from the study area. The interview questionnaire was administered by researchers working in Ethiopian Biodiversity Institute, microbial biodiversity directorate; bacteria and fungus case team. The semi-structured interview questionnaire was pre-tested and adjusted before its full administration [9].

Focus group discussion was made with members composed of representatives of each kebele who were elders and young farmers who have been engaged in farming. Eight to twelve informants in each focus group were included for the study [9].

\section{Data analysis}

Descriptive frequency statistics (Central tendency, dispersion and percentiles) was used to evaluate all the variables using SPSS (2011) software ver.20. ANOVA was done to compare the mean values of the variables. P-value less than 0.5 was taken as significance.

\section{Results and Discussion}

A total of 103 informants were included in this study from 10 kebeles (smallest administrative unit) of the 4woredas (big administrative area comprising 25kebeles on average) in the study area of North Shoa (Table 1).

Table 1: Frequency and percent description of informants in each woreda.

\begin{tabular}{|c|c|c|}
\hline Woreda Name & Frequency & Percent \\
\hline Anegulelana tera & 21 & 20.4 \\
\hline Kewote & 27 & 26.2 \\
\hline Tarma ber & 23 & 22.3 \\
\hline Ankober & 32 & 31.1 \\
\hline Total & 103 & 100 \\
\hline
\end{tabular}

An average of 25 farmer informants with mean age of 44 was included in each woreda. The largest number of informants was
32 and the least was 21 in Ankober woreda and Yeanigulelana tera woreda, respectively (Table 1).

There were 17 focus discussion groups in the 10 kebeles of 4 woredas. The frequency distribution of each discussion group with informants by kebele is shown in Figure 2.

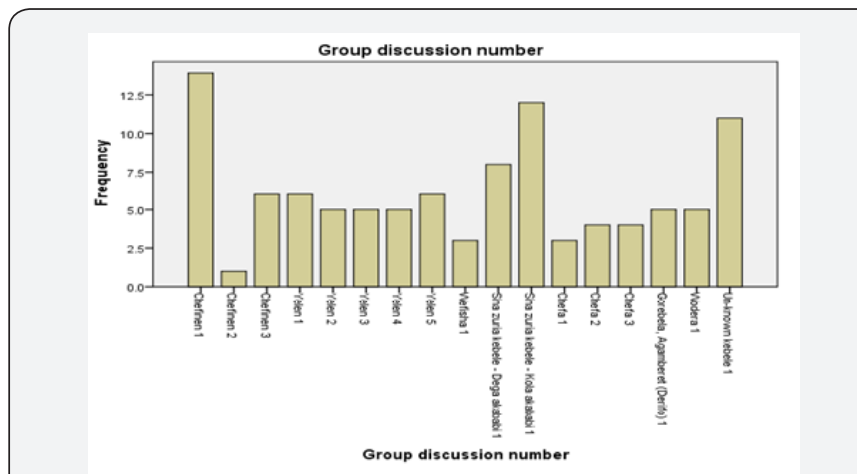

Figure 2: Frequency distribution of informants in each discussion group by kebele.

\section{Characteristics of respondents/informants}

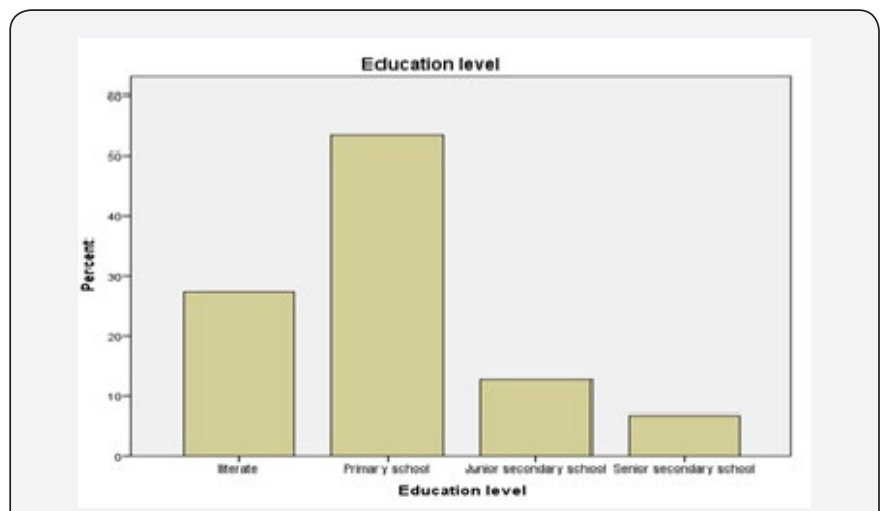

Figure 3: Education level of respondents.

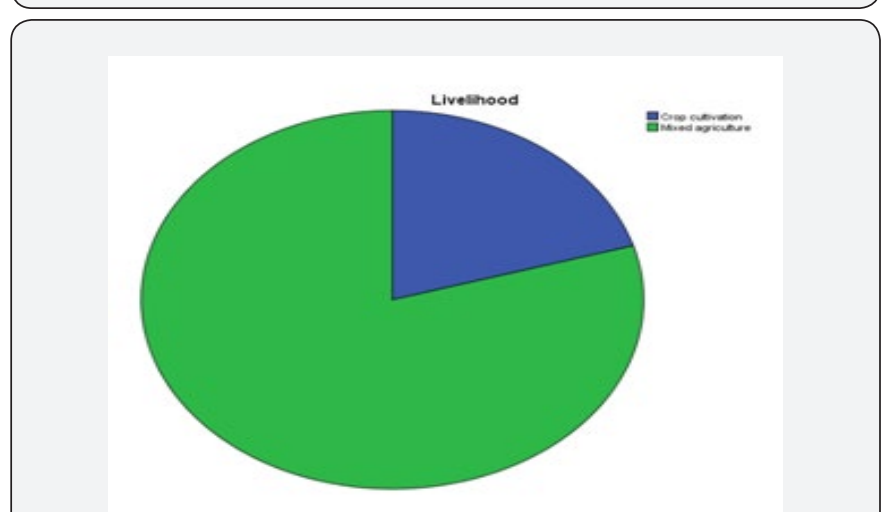

Figure 4: Livelihood of respondents.

The farmer informants who were included in the study are from different age group, education level and livelihood background (Figure $3 \& 4$ ). The mean age of the informants was 44 and with mean family size of 4 . Their education level was also 
different. Twenty seven of them were illiterate and $73 \%$ of them completed either primary and/or secondary school. Eighty two (79.6\%) of the 103 total informants led their life by engaging in mixed agriculture and the rest $21(20.4 \%)$ relied only on crop cultivation.

\section{Farmers' techniques of soil classification}

This study indicated that farmers in North Shoa district have various techniques of traditional practices adopted for classification of soil. They basically use soil color, soil texture and gravel content of the soil. A combination of criteria is also used by them to classify the soil. Seventy one percent of the respondents responded that they use combined criteria of soil colour, texture and gravel content in their traditional soil classification technique. Soil colour and texture is the second combined criterion which accounts $16.5 \%$ of the respondents use. Soil colour alone is also used by the farmers (5.8\%) to classify soil.

Different types of soil colour are used by farmers in all kebeles of the study areas. The major soil colour types used are black, brown, red and gray. The soil colour is not only used to classify soil but also used to assess the soil fertility. They can differentiate the soil fertility by merely looking at the soil colour. The frequently used colour types of soil are black, brown and red. Fifty eight percent of the respondents use a combination of black, brown and red soil colour to classify soil and assess its fertility in traditional way. Black and red soil colour is frequently used by fifteen percent of the respondents to classify soil.

Three major types of soil texture; rough, smooth, and muddy, are most often used by all farmers in the study area. Seventy two percent of the respondents frequently used roughness/ smoothness of soil texture for soil classification. Other studies in various settings of Ethiopia have also shown that farmers commonly classify their soils using a range of well-identified criteria that are relevant to their local situation [13-15]. The most common criteria noted in studies on local systems of soil classification reflect the physical properties of soils, or related factors such as texture, colour and workability $[16,17]$. Farmers are well acquainted with these characteristics through their daily observations of soils, and particularly of their surface [18,19].

\section{Farmers' techniques of soil fertility assessment}

This study indicated that farmers in the study area do have tremendous indigenous and inherent techniques of soil fertility assessment. The soils are classified according to recognizable and easily identifiable soil and field characteristics. Even though they traditionally adopt various techniques of soil assessment, they most frequently use soil colour and texture change, productivity decline, appearance of sand in the field, poor seedling germination immediately after sawing, yellowing and other coloration of crop leaves during crop growth, dicotyledonous weeds occurrence and soil fauna (Earth worm casting activity), soil workability, slope and the soil's depth criteria. Thirty percent of the respondents explained that they use these criteria in combination in their day to day activity of farming. Forty two percent of the respondents use this criterion in combination except soil fauna (Earth worm casting activity) to assess the soil fertility.

Forty eight percent of the respondents explained that they consider the soil is fertile if the soil has black colour and smooth in texture. But, forty two percent of the respondents said that they take the soil fertile if it is also red in colour but smooth in texture. Soil colour is an important criterion for farmers, as it often reflects the soil's hidden parent material, which determines specific soil characteristics. The texture of the surface layer has some influence on many other soil properties, and gives farmers a clear indication as to whether a soil can be cultivated after the first rains of the season. This technique of farmers' soil fertility ranking suggests that in their perception the local soil classification is well correlated with soil fertility and productivity [13-15].

\section{Farmers' methods of cropping systems and their knowledge about the role of microbes associated with legume root nodule}

Farmers in North Shoa district practice different types of cropping systems. They perform one or the other cropping system at different time; Monocropping, crop rotation, and intercropping (sequential cropping, strip cropping and relay cropping). All of the respondents explained that they adopt the traditional crop rotation in their farming system. The most three common farming practices carried out by the farmers in all woredas are; crop rotation (100\%), sequential cropping (94\%), and strip cropping (80\%), respectively.

Farmers are well aware that they can improve soil productivity by rotating crops. Most of them (95\%) explained that they rotate crops from seasons to seasons to improve soil fertility and increase productivity. Around $99 \%$ of the respondents practiced crop rotation in every other year. The most common types of crops they combine during crop rotation are barley, bean, wheat, pea and linseed. Sixty one percent of the respondents follow this combination of cereal and legume crops in their crop rotation farming system. Teff, sorghum and onion are the next common combinations of crops followed by farmers (38\%) to the first mentioned combinations of crops during crop rotation.

Farmers consider different factors in selecting the right crops to combine them for crop rotation system. The major criteria they follow are ability of the crop in improving the soil fertility (93\%), ability of the combined crops in complementing one another (49\%) and ability of the crops in covering the soil (43\%), respectively. Only $28 \%$ of the respondents included in the study accounted the type of roots the crops have is used in selecting the right crops to combine in crop rotation practices. Even though the proportion is low (13\%), farmers living in the study district also have the practice of using fallow land for crop rotation rather than combining crops. They take five 
years on average of duration of fallow land period between two consecutive crop rotations.

More than half of the farmers (55\%) are not aware of the difference between the root types of cereal and legume crops. Seventy eight percent of the farmers do not have the knowhow about the association among the roots, root nodules and $\mathrm{N}_{2}$ fixation carried out by microbes associated with legume roots. But, in the contrary to this fact $98 \%$ of the respondents are found to have the knowledge about the importance/the role of legume crops during crop rotation in the improvement/enhancement of soil fertility. This indicates that most farmers living in the study area are aware of the role of legumes in soil improvement but they do not have the scientific background about the role of microbes associated with legume root nodules in the enhancement of soil fertility.

\section{Conclusion}

The most three common traditional farming practices identified in the different parts of North Shoa, Ethiopia, particularly by small-scale traditional farmers are; crop rotation, sequential cropping, and strip cropping, respectively. The most common types of crops they combine during crop rotation are barley, bean, wheat, pea and linseed. Even though the proportion is low, farmers living in the study district also have the practice of using fallow land for crop rotation rather than combining crops. They take five years on average of duration of fallow land period between two consecutive crop rotations. Farmers in the study area do have tremendous indigenous and inherent technique of soil fertility assessment. Farmers in the study area perceive soil fertility closely related to crop productivity. The local system for classifying soils is based mainly on soil colour, texture and depth. This study in addition found out that most farmers living in the study area are aware of the role of legumes in soil improvement but they do not have the scientific background about the role of microbes associated with legume root nodules in the enhancement of soil fertility.

\section{References}

1. Massawe PI, Mtei KM, Munishi LK, Ndakidemi PA (2016) Improving Soil Fertility and Crops Yield through Maize-Legumes (Common bean and Dolichos lablab) Intercropping Systems. Journal of Agricultural Science 8(12).

2. Brooker RW, Bennett AE, Cong WF, Daniell TJ, George TS, et al. (2015) Improving intercropping: a synthesis of research in agronomy. Plant physiology and ecology New Phytologist 206(1): 107-117.
3. Baldwin KR (2006) Organic production-Crop rotations on organic farms. Centre for environmental farming system.

4. Wang ZG, Jin X, Bao XG, Li XF, Zhao JH, et al. (2014) Intercropping Enhances Productivity and Maintains the Most Soil Fertility Properties Relative to Sole Cropping. PLoS ONE 9(12): e113984.

5. Papanastasis VP, Arianoutsou M, Lyrintzis G (2004) Management of biotic resources in ancient Greece," in Proc. $10^{\text {th }}$ Mediterranean Ecosystems (MEDECOS) Conference, Rhodes, Greece 25: 1-11.

6. Plucknett DL, Smith NJH (1986) Historical perspectives on multiple cropping, in Multiple Cropping Systems. CA Francis (Ed.), MacMillan Publishing Company, New York, USA.

7. Altieri MA (1991) Traditional farming in Latin America. The Ecologist 21(2): 93-96.

8. Altieri MA (1999) The ecological role of biodiversity in agroecosystems. Agr Ecosyst Environ 74: 19-31.

9. McCann JC (2017) Oxford Research Encyclopedia of African History: The History of Agriculture in Ethiopia.

10. Encyclopaedia Britannica (2017) Shewa. Encyclopaedia Britannica, Inc.

11. Grenier L (1998) Working with indigenous knowledge: A guide for researchers. International Development Research Centre, Ottawa, ON, Canada K1G 3 H9.

12. Pretty J, Guijt I, Thompson J, Scoones I (1995) A trainer's guide for participatory approaches. IIED, London, UK.

13. Mitiku H (1996) Soil resources of Central Tigray: a case study of selected farms in 7 weredas. In: AO Øyhus, G Gebru (Eds.), Rural exploratory studies in the central zone of Tigray, Northern Ethiopia. Proceeding of a workshop, Noragric, Addis Ababa, Ethiopia, pp. 19-33.

14. Corbeels M, Shiferaw A, Haile M (2000) Farmers' knowledge of soil fertility and local management strategies in Tigray, Ethiopia. Managing Africa's Soils: No.10.

15. Ayalew G (2015) Assessment of Traditional Soil Fertility Classification and its Management Practices in the Five Districts, Northwestern Highlands of Ethiopia. Journal of Resources Development and Management 5.

16. Talawar S, Rhoades RE (1997) Scientific and local classification and management of soils. Agric Human Values 15(1): 3-14.

17. Tamang D (1993) Living in a fragile ecosystem: indigenous soil management in the hills of Nepal. Gatekeeper Series No. 41. IIED. London, UK.

18. Habarurema E, Steiner KG (1997) Soil suitability classification by farmers in Southern Rwanda. Geoderma 75(1-2): 75-87.

19. Kanté S, Defoer T (1994) How farmers classify and manage their land: implications for research and development activities. IIED Dryland Networks Programme, Issue Paper No. 51, London, UK. 


\section{Agricultural Research \& Technology: Open Access Journal}

This work is licensed under Creative Commons Attribution 4.0 License

DOI:10.19080/ARTOAJ.2018.13.555891
Your next submission with Juniper Publishers will reach you the below assets

- Quality Editorial service

- Swift Peer Review

- Reprints availability

- E-prints Service

- Manuscript Podcast for convenient understanding

- Global attainment for your research

- Manuscript accessibility in different formats ( Pdf, E-pub, Full Text, Audio)

- Unceasing customer service

Track the below URL for one-step submission https://juniperpublishers.com/online-submission.php 